\title{
Teologia do brinquedo: a vida e corpo como fins em si mesmos em Rubem Alves
}

\author{
Theology of the toy: the life and body as ends \\ in themselves in Rubem Alves
}

\section{Teología del juguete: la vida y el cuerpo como fines en sí mismos en Rubem Alves}

\author{
Roberto Carlos Conceição Porto*
}

\begin{abstract}
RESUMO
Esta pesquisa se propõe a analisar a teologia do brinquedo de Rubem Alves. O tema aparece em um pequeno capítulo do livro "variações sobre a vida e a morte" (1981). Contudo, embora curto, o texto é denso e inovador. Alves entende que a importância do brincar está no fato de ser um fim em si mesmo. Brincando, o desejo se torna prazer e reinventa toda a realidade, livre de amarras e opressão. O brinquedo permite compreender que a vida, o corpo e as atividades humanas são fins em si mesmos e não um meio para se alcançar alguma coisa. Desta forma, o brinquedo é, assim, uma denúncia à lógica do mundo adulto. A teologia, para ser palavra que liberta, precisa, antes, ser amiga da palavra que brinca.

Palavras-chave: Rubem Alves; teologia do brinquedo; desejo; prazer; fins em si mesmos.
\end{abstract}

\begin{abstract}
This research proposes to analyze the theology of the toy of Rubem Alves. The theme appears in a short chapter in the book "Variations on Life and Death" (1981). However, although short, the text is dense and innovative. Alves understands that the importance of playing is that it is an end in itself. Playing, desire becomes pleasure and reinvents all reality, free from tyrannies and oppression. The toy allows us to understand that life, body and human activities are ends in themselves and not a means to achieve something. In this way, the toy is thus a denunciation of the logic of the adult world. Theology, in order to be a liberating word, must first befriend the word that plays.

Keywords: Rubem Alves; theology of the toy; desire; pleasure; ends in themselves.

\section{RESUMEN}

Esta investigación se propone analizar la teología del juguete de Rubem Alves. El tema aparece en un pequeño capítulo del libro "variaciones sobre la vida y la muerte" (1981). Sin embargo, aunque corto, el texto es denso e innovador. Alves entiende que la importancia del juego está en el hecho de ser un fin en sí mismo. Jugar, el deseo se vuelve placer y reinventa toda la realidad, libre de amarras y opresión. El juguete permite comprender que la vida, el cuerpo y las actividades humanas son fines en sí mismos y no un medio para alcanzar algo. De esta forma, el juguete es, así, una denuncia a la lógica del mundo adulto. La teología, para ser palabra que libera, necesita, antes, ser amiga de la palabra que juega.

Palabras clave: Rubem Alves; teología del juguete; deseo; placer; fines en sí mismos.
\end{abstract}

* Mestre em Ciências da Religião pela Universidade Metodista de São Paulo (Umesp). E-mail: obr. robertocarlos@hotmail.com 


\section{Introdução}

Rubem Alves começou a desenvolver uma "teologia do brinquedo" a partir da década de 1980, especialmente com a obra "Variações sobre a vida e a morte" (1981). O tema ocupa um pequeno capítulo do livro, contudo, as reflexões que Alves apresenta são inovadoras.

Alves conta que a ideia de uma teologia do brinquedo lhe ocorreu após um convite inusitado, que já há algum período não acontecia: um convite para fazer uma pregação em uma igreja presbiteriana. Desta vez, o teólogo tinha se proposto a não tocar em temas polêmicos. Para isto, ele resolveu pregar sobre um texto bíblico do Novo Testamento sobre as crianças. Entretanto, aos poucos, ele percebeu que o texto sagrado falava mais sobre os adultos do que propriamente das crianças. E o resultado foi catastrófico... (ALVES, 1982, p. 165-166).

Para entender a importância de uma "teologia do brinquedo" para Alves é necessário, antes, situar sua compreensão sobre a teologia e a centralidade do corpo humano. Feito isto, passar-se-á à teologia do brinquedo propriamente dita.

\section{Reinventar a teologia}

No nono capítulo do livro "Variações sobre a vida e a morte: a teologia e sua fala" (publicado em 1981), Rubem Alves se dedica a uma "teologia do brinquedo". ${ }^{1}$ Contudo, o livro, de forma geral, retrata a situação da teologia e dos/as teólogos/as em uma sociedade dominada pelo cientificismo positivista (REBLIN, 2009, p. 152-153).

A partir da Modernidade, especialmente com a "Modernidade Madura" e o iluminismo (DUSSEL, 2007), ${ }^{2}$ a se forma a ciência moderna: a positivista. Segundo Boaventura de Sousa Santos, esta ciência se baseava nas ciências naturais para explicar a sociedade e se

assentava nas seguintes ideias fundamentais: distinção entre sujeito e objeto e entre natureza e sociedade ou cultura; redução da complexidade do mundo a leis simples susceptíveis de formulação matemática; uma concepção de realidade dominada pelo mecanicismo determinista e da verdade como representação transparente da realidade;

O capítulo está intitulado como “... E das crianças” (ALVES, 1982, p. 165).

2 Modernidad temprana e Modernidad madura são expressões de Enrique Dussel. A primeira teria se iniciado em 1492, começo da colonização das Américas, e a segunda por volta do século XVII, onde a Europa alcança uma aceleração no nível técnico-industrial, resultando em uma "decolagem" civilizatória e uma hegemonia econômica, política, militar e cultural (DUSSEL, 2007, p. 141-142, 323). 
uma separação absoluta entre conhecimento científico - considerado o único válido e rigoroso - e outras formas de conhecimento como o senso comum ou estudos humanísticos; privilegiamento da causalidade funcional, hostil à investigação das "causas últimas", consideradas metafísicas, e centradas na manipulação e transformação da realidade estudada pela ciência (SANTOS, 2008, p. 35).

Desta forma, é possível perceber que o/a teólogo/a, que fala, "só fala" (ALVES, 1982, p. 15), para dar legitimidade ao seu discurso - sobre o divino - necessita mudar "as vestes" de sua fala e "vesti-la" com outras ciências: "E o teólogo - por derrota ou amor, não importa - se entrega a outros jogos, seja a sociologia, seja a psicanálise, seja a política. E então, e não sem um certo constrangimento, ele muda suas coisas e palavras dos espaços da metafísica e as entulha nas cavernas da ideologia ou da neurose" (ALVES, 1982, p. 19).

Qual a proposta de Alves, então? Primeiro, entender que a "teologia é uma função natural como sonhar, ouvir música, beber um bom vinho, chorar sofrer, protestar, esperar..." (1982, p. 21), ou seja, é um discurso que provém das experiências humanas. "Ela simplesmente brota e desdobra, como manifestação de uma maneira de ser: 'suspiro da criatura' - seria possível uma definição melhor?” (1982, p. 21). ${ }^{3}$

Após compreender a teologia como proveniente das experiências humanas, Alves propõe abordá-la como um jogo. "Um jogo que se joga quando a vida está em jogo”, como diz Iuri Reblin (2009, p. 153), um dos melhores intérpretes do pensamento de Alves.

Aludindo ao livro de Herrmann Hesse, O jogo das contas de vidro, Rubem Alves assevera que a teologia é uma brincadeira que se faz com os símbolos de que se dispõe tal como os monges de Castália faziam em suas 'contas de vidro': eles criavam variações sobre um tema que lhes era proposto. A partir das contas de vidro teológicas (os símbolos, os mitos, os ritos, as preces, as poesias, as estórias, as visões utópicas, as maldições, as esperanças, etc.) os teólogos e teólogas tecerão sua variação sobre o tema que lhes é dado: o corpo humano. Este é o tema inicial de toda teologia (REBLIN, 2009, p. 153).

Aqui está um tema central do pensamento de Alves: o corpo. Não é possível compreender sua "teologia do brinquedo" sem, antes, analisar sua compreensão de corporeidade.

3 Leopoldo Cervantes-Ortiz denomina a teologia de Alves de "teopoética", pois é "uma forma de reflexão teológica dominada, não pelas influências escolásticas da teologia dogmática ou sistemática, mas na linha do diálogo ludo-poético-erótico, ou seja, uma aproximação pessoal, subjetiva, estética, às verdades religiosas" (2007, p. 240). 


\section{O corpo em Rubem Alves}

Segundo Juan Jacobo Tancara (2007, p. 192), o corpo é o ponto de partida no pensamento de Alves. "No princípio era o corpo" (ALVES, 1987, p. 155). "Partir do corpo. Não é o corpo o centro absoluto de tudo, o sol em torno do qual gira o nosso mundo?" (ALVES, 1982, p. 32).

Como observou Reblin (2009, p. 99-100), em Alves, a experiência sobre Deus é transmitida através de palavras e ações humanas. E estas por meio do corpo, pelo o corpo e com o corpo. Desta forma, a reflexão teológica é reflexão "sobre o corpo, sobre o corpo que espera, sobre o corpo que angustia, sobre o corpo que sofre, sobre o corpo que sente, sobre o corpo que ama".

E não me venham com o chavão de que a preocupação com o corpo é doença de pequena-burguesia. Como se os trabalhadores não tivessem corpos, e sentissem dor de dentes com os dentes de sua classe social, e fizessem amor com os genitais de sua classe social, e cometessem suicídio com a decisão de sua classe social. O corpo, na verdade, é a única coisa que eles possuem - e têm de alugar (ALVES, 1982, p. 33).

Assim, Alves entende que "cada corpo é o centro do mundo" (1982, p. 37) e "os limites do meu corpo denotam os limites do meu mundo" (1982, p. 37). Ou seja, o mundo se estrutura em torno do corpo. O mundo se torna, assim, uma extensão do corpo. "Todas as invenções humanas ${ }^{5}$ foram criadas pelo corpo e em benefício deste corpo" (1987, p. 155). Não existe mundo neutro porque não há corpo neutro. Nem mesmo a ciência é neutra, mas extensão do corpo, pois "também a ciência jaz em uma crença, não há ciência sem pressuposições” (NIETZSCHE, 1887, p. 261). ${ }^{6}$

Desta forma, o corpo humano não está limitado às funções biológicas. Ele pode transformar o mundo de acordo com sua vontade (ALVES, 1999, p. 12). E aqui encontra-se mais um aspecto central do pensamento de Alves.

\section{Corpo e desejo}

"Desejo" e "prazer" são outros termos centrais no pensamento de Alves. Isto se deve, sem dúvida, a sua experiência como psicanalista. Romualdo Dias,

4 Diferentemente de Leopoldo Cervantes-Ortiz, por exemplo, que diz que, para Alves, é "la religión como punto de partida" (2005, p. 101) ou "uno de los temas que más han apasionado a Alves y al cual le ha dedicado vários libros es la religión" (2005, p. 102).

5 Alves se refere aqui aos instrumentos, sociedade, religião, ideologias, ciência e qualquer coisa que possa ser considerada como criada pelo ser humano (cf. ALVES, 1987, p. 155).

6 Esta obra de Nietzsche encontra-se disponível em: https://archive.org/details/bub_gb_LNEuAAAAYAAJ. Acesso conferido pelo editor em 04/05/2020. 
por exemplo, afirma que ler um livro de Alves é semelhante a uma situação em análise, "quando nos deitamos no divã e cumprimos o acordo de falar pelo uso da livre associação" e que ele pratica "em sua escrita a mesma escuta flutuante exercida na clínica de Psicanálise” (2007, p. 255).

Uma palavra importante em Freud é Trieb, que pode ser traduzida por "pulsão", "impulso". Com ela, o psicanalista quer indicar o que seria a natureza animal presente no ser humano, especialmente no seu aspecto irracional, agressivo e sexual, mostrando sua influência da "vontade" [Wille] de Schopenhauer, onde o Trieb freudiano e a Wille schopenhaueriana são praticamente sinônimos.

Com o termo "libido", Freud pôde enriquecer sua concepção de ser humano marcado pela pulsão. Libido expressa a energia que dinamiza a vida humana e satisfaz o Trieb. Inicialmente, o "pai" da psicanálise usava o termo para designar a energia sexual. Contudo, em seu período mais tardio, o termo passou a compreender toda a energia psíquica (FODOR; GAYNOR, 1950, p. 115-116; HELLER, 2005, p. 164). ${ }^{7}$

Em Psychoanalyse und Libidotheorie [psicanálise e teoria da libido], Freud define assim a libido:

A pulsão sexual [Sexualtrieb], cuja expressão dinâmica na vida psíquica é nomeada "libido", é composta de pulsões parciais [Partialtrieben], nas quais ela pode desintegrar-se e unir-se de determinadas organizações semelhantes. Fonte destas pulsões parciais [Partialtriebe] são os órgãos corporais, especialmente certas zonas erógenas excelentes, mas contribuições para a libido também são distribuídas por todos os processos funcionais importantes no corpo. Primeiramente, a única pulsão parcial esforça-se por satisfação independentemente uma da outra, contudo, com o decorrer do processo, torna-se cada vez mais reunida, centrada (FREUD, 1967, p. 220).

Assim, contrariando o que se acreditava até então, Freud explica que o narcisismo é um fenômeno normal do desenvolvimento psíquico quando a libido é retirada de seu objeto de desejo, isto é, quando a pulsão do ego e a pulsão sexual não estão separadas, o desenvolvimento psíquico faz com que a pulsão do ego e o objeto de amor se correspondam (LOHMANN; PFEIFFER, 2013, p. 154-155).

O problema, isto é, a neurose, surge quando a pulsão do ego não se realiza no objeto de libido. Em outras palavras, quando o desejo não se torna prazer. Para Freud, o ego é capaz de produzir "mecanismos de defesa". Um deles é

7 Em Das Unbehagen in der Kultur (1955, p. 419-506), Freud explica que a criação da cultura/civilização moderna se fez a partir da unidade, contrariando o impulso humano constituído de agressividade e desejo sexual, resultando em um mal-estar cada vez maior. 
a "repressão" [Verdrängung]: o indivíduo "torna-se cego e surdo", vivendo na realidade de sua "imaginação" [Phantasie] em um mundo de "faz de conta".

Desta forma, percebe-se que, para Freud, o ser humano é um ser de desejo. E Alves o acompanha: “O corpo faz seus desejos” (1982, p. 162).

\section{A criança}

Explicada a compreensão de Alves sobre a situação da teologia em uma sociedade dominada pelo cientificismo positivista, a centralidade do corpo em suas reflexões e a importância da psicanálise, aborda-se, agora, a teologia do brinquedo, tema que esta pesquisa se propôs.

Para tanto, antes de interpretar o brinquedo, é necessário entender a criança. Alves recorda a tradição neotestamentária que afirma que, quem não se torna uma criança, não pode herdar o Reino dos Céus (Evangelho Segundo Mateus 18.3; ALVES, 1982, p. 165).

A criança é vista, na sociedade atual, como símbolo da inocência e pureza. Basta recordar, por exemplo, o conto "A roupa nova do rei", do dinamarquês Hans Christian Andersen. Embusteiros fingem-se de alfaiates e fazem uma nova roupa para o rei. O tecido, contudo, seria de um material raro: apenas os inteligentes poderiam vê-lo. Ninguém conseguia enxergar a esplêndida roupa, mas o orgulho os impedia de confessar. Até que o monarca é desmascarado: “O rei está nu!", grita a criança, a voz do ser supostamente mais inocente e puro.

Contudo, "parece que o mito de sua inocência e pureza morreu, faz muito tempo. Freud foi o coveiro. Exemplos de amor também não são. Seu narcisismo é por demais evidente: só veem a si mesmas" (ALVES, 1982, p. 166). Não só o fundador da psicanálise, mas também Jean Piaget contribuiu para acabar com o mito da pureza e inocência infantil.

Com uma afirmação que causa mal-estar em alguns ainda hoje, Freud chegou à conclusão que as crianças já possuem sexualidade. Embora ele diga que não conheça nenhum autor que tenha reconhecido a sexualidade infantil com tanta clareza como ele (FREUD, 1968, p. 74), outros pesquisadores antes dele - isto é, antes do século XX - já haviam sinalizado para a existência da "experiência sexual" infantil.

Assim, Lohmann e Pfeiffer argumentam que a contribuição freudiana não foi alertar sobre a sexualidade infantil, mas que as neuroses ocorridas durante o tempo de desenvolvimento da sexualidade das crianças têm efeito na vida adulta (2013, p. 147).

Para Freud, a sexualidade infantil é autoerótica, ou seja, o objeto da libido está em seu próprio corpo e só posteriormente se direciona para 
um corpo estranho (FREUD, 1968, p. 98; 1967, p. 221). A sexualidade está dividida entre período pré-genital (três fases) e o período genital (latência).

$\mathrm{Na}$ sexualidade infantil, o período pré-genital se inicia com a fase oral. $\mathrm{A}$ atividade sexual está intimamente relacionada à nutrição, sendo a boca $\mathrm{O}$ órgão erógeno e pelo qual a criança começa a conhecer o mundo. A segunda fase é a anal, sendo que ainda não é possível nomeá-la de atividade sexual masculina ou feminina, mas passiva ou ativa. A criança passa, agora, a ter controle sobre a musculatura. O ânus é a zona erógena e a fezes o produto de afetividade. Por fim, a última fase do período pré-genital é a fálica, onde a zona erógena são os genitais e há a preocupação da criança pela diferenciação entre meninos e meninas (FREUD, 1967, p. 98-100).

Por fim, o período genital é a fase da latência [Latenq], onde ocorre a repressão [Verdrängung], ou seja, a canalização da libido para o desenvolvimento da vida social (FREUD, 1967, p. 100-101). ${ }^{8}$

Piaget, por outro lado, também classificou o desenvolvimento infantil em quatro períodos (VIOTTO FILHO; PONCE; ALMEIDA, 2009, p. 33):

- Sensório-motor: aproximadamente entre 0 e 2 anos, há o uso da memória, imitação e pensamento. As ações já começam a ser voltadas para um objetivo;

- Pré-operacional: aproximadamente entre 2 e 7 anos, desenvolve a linguagem e consegue pensar simbolicamente. É egoísta, no sentido piagetiano;

- Operacional concreto: aproximadamente entre 7 e 11 anos, resolve problemas práticos de forma lógica e compreende a "conservação da matéria, do peso e do volume";

- Operacional formal: aproximadamente dos 11 anos à vida adulta, resolve problemas abstratos de forma lógica, pensa de forma mais científica sobre a sociedade e si mesmo.

O que é preciso destacar é que, até a fase pré-operacional, a criança é egoísta, ou seja, ainda há uma falta de consciência do ego, de modo que não consegue se distinguir do mundo exterior e acredita ser o centro do mundo.

\section{O brinquedo}

Se para Émile Durkheim, por exemplo, a educação é um "fato social”, ou seja, um fato geral, coercitivo e externo, e a sociedade tende a ter primazia

\footnotetext{
Cf. nota 8 .
} 
sobre o individual. A educação, como fato social, assume um caráter de coerção externa dos adultos sobre as crianças. Consequentemente, o brinquedo, na concepção durkheimiana, se torna um meio privilegiado de socialização infantil: as meninas brincam de boneca desde cedo para, ao crescerem, se tornarem domésticas e os meninos, desde pequeninos, dirigem seus carros de plástico e jogam futebol... (DURKHEIM, 2007).

Contudo, para Alves, o brinquedo tem outro significado: "Brinquedo é uma atividade não produtiva. Ele não tem por objetivo a produção de qualquer objeto" (ALVES, 1982, p. 166).

Se brincar não é uma atividade produtiva, então por que as crianças brincam? "O brinquedo não produz objetos, mas ele produz prazer. Se a palavra prazer parece por demais erótica e sensual podemos muito bem usar uma outra, dotada de maior respeitabilidade teológica: alegria" (ALVES, 1982, p. 166).

Alves recorre a Santo Agostinho para se explicar melhor: Agostinho distinguia entre coisas que devem ser "usadas" e coisas que devem ser "desfrutadas". Quando se usa algo - que pode ser um objeto, uma palavra, uma pessoa -, este é sempre um meio para determinado fim; quando algo é para ser desfrutado, significa que é um fim em si mesmo. Isto é um brinquedo: um fim em si mesmo, para ser desfrutado e gerar prazer (ALVES, 1982, p. 167).

A importância desta compreensão acerca do brinquedo resulta que, para as crianças, o desejo se torna primaz e as fantasias que ele produz transformam-se em atividades ou coisas. A realidade, com todos seus mecanismos repressivos, é abolida e reconstruída a partir das "leis" do desejo, mediante as fantasias e sonhos, ou seja, por meio de um "faz de contas" possui-se coragem para "fazer e dançar" os desejos (ALVES, 1982, p. 167-168).

Para Alves, o prazer não é um meio para alguma coisa, mas justamente o contrário: tudo é meio para que o prazer, expressado no desejo, se realize. "No prazer o desejo chegou ao seu destino" (ALVES, 1982, p. 169) e o corpo, que deseja, é um "brinquedo brincante" (ALVES, 1982, p. 170). Em suma, é possível destacar que, em Alves, a importância do brinquedo baseia-se em ser um fim em si mesmo, de modo que o brincar, gerando prazer, é uma atividade para ser desfrutada e não para realizar produtividade como um meio.

\section{O ascetismo protestante e a produção como um meio}

Embora o que o ser humano "produza" deva ser um fim em si mesmo, a produção começou a tratada e empregada como um meio para algo. Alves lembra que, provavelmente, esta inversão tenha começado com o surgimento 
da burguesia, especialmente com a protestante-calvinista (ALVES, 1982, p. 171). Alves se baseia, então, nas teses de Max Weber, a partir da famosa obra "A ética protestante e o espírito do capitalismo".

Weber considera, para estudar a relação entre protestantismo e capitalismo, a racionalidade. O sociólogo alemão observou que apenas o ocidente desenvolveu um certo tipo de racionalidade. Posteriormente, esta racionalidade resultou em racionalização em todas as áreas da vida.

Assim, a ideia de "vocação" cristã - que Lutero traduziu no Novo Testamento como Beruf, "profissão" -, desempenhou um papel importante. Primeiramente, a vocação começou a ser entendida como uma "moralidade intramundana" [innerweltliche Sittlichkeit], ou seja, diferentemente dos mosteiros ascéticos católicos, localizados em um lugar separado da sociedade, os calvinistas passaram a possuir uma moralidade ascética "dentro do mundo" (WEBER, 2016, p. 171).

Consequentemente, afirma Weber, a ascese cristã e a "conduta de vida racional" [Rationale Lebensführung] implicaram-se e tornaram-se sinônimos: a ascética tornou-se racional e a racionalização ascética (WEBER, 2016, p. 79, 170).

Hans-Peter Müller e Steffen Sigmund argumentam que os calvinistas, especialmente os puritanos, interpretaram a tradição bíblica, católica e luterana de amor ao próximo como o cumprimento de uma tarefa de vocação, dando-lhe um caráter coisificado e impessoal, possibilitando que a caridade se tornasse amor a si mesmo (2014, p. 252).

Assim, com uma ascese intramundana racional e a vocação compreendida em um sentido egocêntrico, a riqueza passou a ser, para tais puritanos, sinal de eleição: a riqueza se tornava, assim, o sinal visível de uma escolha divina e de salvação invisível:

Mas aí apareceu um grupo diferente de gente diligente, [...] gente que trabalhava com afinco, dia e noite, e lia, nas horas vagas, as cartilhas calvinistas, onde aprenderam que a riqueza era o sinal visível da graça invisível da salvação; quanto mais rico mais salvo, quanto mais salvo mais rico. [...] E esta nova estirpe de santos ricos aprendeu logo que o corpo é mau conselheiro em assuntos de riqueza e de trabalho, pois que prefere gastar a ganhar, prefere o ócio ao suor, prefere o prazer à disciplina (ALVES, 1982, p. 171).

$\mathrm{O}$ ascetismo intramundano protestante, em uma sociedade de capitalismo em desenvolvimento, resultou em uma lógica de que toda atividade humana é um meio para demonstrar a eleição divina e, consequentemente, a salvação. 


\section{A desvalorização do corpo}

Embora o puritanismo calvinista tenha contribuído para a desvalorização do corpo e seu tratamento como um meio para determinado fim, Alves lembra que a corporalidade, no ocidente, nunca foi muito valorizada.

Basta recordar, por exemplo, Platão e sua antropologia dualista. O ser humano é corpo e alma. Contudo, tudo o que é material não é confiável: o mundo, os sentidos, o corpo. Importante mesmo são as ideias. A matéria é corruptível. Para alcançar o conhecimento, deve-se partir das ideias.

\footnotetext{
As determinações classificatórias, que foram reconstruídas no quadro das perspectivas "zoológicas" e "teológicas", tornam-se própria e claramente uma condição de tensão: o ser humano aparece como uma dupla natureza animalesca e divina, que participa simultaneamente do mundo dos mortais e do mundo dos imortais, embora com uma inegada tendência "para o alto". Esta posição antropológica intermediária, que já Heráclito havia formulado antes de Platão, reflete a ideia platônica fundamental de metaxy, que também parece desempenhar, de forma geral, um papel para situar ontologicamente a alma (HORN; MÜLLER; SÖDER, 2009, p. 195).
}

Sendo animal e divino, é assim que a desvalorização do corpo, com prioridade para o "espírito", se introduz no ocidente. A partir de Santo Agostinho, Platão e a filosofia neoplatonista, com sua divisão dualista, se introduzem no cristianismo. Por tal recepção, o bispo de Hipona chega até mesmo a considerar o desejo sexual como algo ruim e resultado direto da queda, sendo o sexo, mesmo antes do pecado de Adão e Eva, destinado à procriação (HUNTER, 2012, p. 359). "Pena que Agostinho [...] não tivesse se permitido sorrir diante desta dádiva de Deus, transformando o jogo sexual do amor em simples meio para um fim demográfico: a reprodução e a população dos céus...” (ALVES, 1982, p. 170).

Para Alves, o cristianismo, de forma geral, contribuiu para a desvalorização do corpo. Seria suficiente levar em consideração, por exemplo, o desprestígio que o livro bíblico Cântico dos cânticos, os "poemas eróticos de Salomão" (ALVES, 1982, p. 173), recebe dos cristãos: é considerado inspirado divinamente, mas não é usado como base de homílias e prédicas... E quando o é, emprega-se alegorias, transformando o corpo em "algo que não é corpo, nem homem, nem mulher" (ALVES, 1982, p. 173).

\section{A racionalização e a produção de mais-valia}

Alves lembra que, a partir da lógica econômica, o corpo pode ser considerado como "ineficaz". Se as reflexões de Freud, de que o ser humano é um 
ser de desejo, estão corretas, então, a partir da lógica capitalista - "produzir mais com menos para gerar lucro" - o corpo não é eficaz. "Reprime-se o corpo por amor à eficácia. O corpo, por si, é ineficaz. Ele não está em busca de objetos; só deseja o prazer" (ALVES, 1982, p. 174).

Aqui, novamente, Alves se baseia em Weber. "É a própria 'racionalidade' do sistema de produção que o exige" (ALVES, 1982, p. 174). Como foi dito mais acima, o sociólogo de Heidelberg acreditava que apenas no ocidente se desenvolveu um certo tipo de racionalidade. Müller e Sigmund resumem satisfatoriamente, em algumas linhas, os três " $\mathrm{R}$ " - racionalidade, racionalização e racionalismo - de Weber:

Primeiro, os três "R" não estão localizados em um nível, mas são elementos constitutivos de uma arquitetônica de mesmo plano da sociologia weberiana: racionalidade relaciona-se ao nível micro, racionalização ao nível médio e racionalismo ao nível macro. Schluchter (2005) trouxe a fórmula de "ação, ordem e cultura", a qual deve orientar o programa de pesquisa de Weber. Embora esta subdivisão seja algo geral, não obstante, presta-se a fins de orientação e de sistematização. "Racionalidade" relaciona-se com a ação - aqui domina a diferenciação entre racionalidade de fins ${ }^{9}$ e racionalidade de valor; "racionalização" visa a organizações e ordem - aqui, Weber opera com a distinção, como é segurada na conceitualidade da sequência, entre a racionalidade formal e material; "racionalismo" estende-se à cultura ou, na linguagem weberiana: às imagens de mundo - aqui domina a diferenciação entre racionalismo teorético e prático. $\mathrm{O}$ ocidente moderno distingue-se através de um assim chamado racionalismo de domínio do mundo (Schluchter 1980) com uma liga característica de racionalismo teorético e prático (MÜLLER; SIGMUND, 2014, p. 108).

Com o capitalismo, para Weber, opera-se a organização racional do trabalho contratual a partir da força de trabalho livre. É racional porque a estrutura capitalista é burocratizada. Para a expansão do empreendimento, necessita-se de cálculos, desde o campo de ação à técnica utilizada. Para administrar a máquina capitalista, precisa-se de mão de obra qualificada. Desta forma, para maior eficácia, reprime-se o corpo para que produza mais (cf. MÜLLER; SIGMUND, 2014, p. 72-73).

A isto, acrescentam-se as contribuições de Marx. Para o filósofo alemão, o "capital" não é nem uma medida de mercadoria nem uma soma de dinheiro. Antes, é o "valor que se valoriza" [sich verwertenden Wert], ou seja, o valor que se acumula. Assim, troca-se dinheiro por mercadoria e esta é trocada por uma quantidade de dinheiro maior. A diferença entre a quantia de

\footnotetext{
9 No mundo lusófono, traduziu-se Zweckrationalität por "racionalidade instrumental". Contudo, a tradução literal é "racionalidade de fins", isto é, Zweck significa precisamente "fins", "alvo", "objetivo", assim, uma racionalidade com objetivos determinados e não neutra em si.
} 
dinheiro que retorna e a que se paga é nomeada, por Marx, como mais-valia. ${ }^{10}$ A acumulação crescente de mais-valia é o objetivo do capital (QUANTE; SCHWEIKARD, 2016, p. 174).

Contudo, Marx observou que esta acumulação não ocorre apenas nos objetos vendidos. Há uma mercadoria específica que permite a acumulação por parte do dono do capital: a força de trabalho. Os/as trabalhadores/as não vendem seu trabalho, mas sua habilidade de trabalhar. A atividade do/ da trabalhador/a é trabalho vivo. Entretanto, remunera-se apenas o trabalho que produz e não a força de trabalho. Para Marx, isto é exploração. Assim, há aqui, também, mais-valia (QUANTE; SCHWEIKARD, 2016, p. 174-175).

Os resultados são drásticos. "E o corpo, como ser erótico brincante, se reduz à condição de puro meio, entidade manipuladora cujo objetivo é a produção de lucro. Desaparecem os sentidos ligados à vida e são substituídos por um único sentido, o sentido do ter" (ALVES, 1982, p. 175). Em um mundo ocidental onde, desde cedo, desvalorizou-se o corpo, considerou-se como má a vontade sexual, desenvolveu-se um sistema econômico que exigia a repressão e a racionalização para a eficácia do corpo, a produção de lucro e uma religiosidade que tendia à desvalorização da corporalidade.

A justificação pelas obras é como o processo de produção. Importa o que vem no final. O corpo é um meio para alcançar a salvação, a mercadoria. "E o corpo e o brinquedo? Reduzidos à condição de atividade necessária para que o corpo se mantenha no seu ótimo nível de produtividade, [...] tal como os aviões que, de tempos em tempos param de voar e são mandados para a revisão..." (ALVES, 1986, p. 176).

Contrariamente a tudo isto, Alves entende que a vida e o corpo são fins em si mesmos e não meios para alguma coisa (1982, p. 177). Teologicamente, a justificação pela fé soa melhor, pois "significa precisamente o abandono total do esforço para se encontrar o sentido para a vida em termos dos resultados práticos de nossa atividade" (ALVES, 1982, p. 177).

\section{Os adultos também brincam...}

Na sociologia, o conceito de "papéis sociais" é importante. Os indivíduos seriam, antes de tudo, atores sociais. Desta forma, do "ator" pai, por exemplo, espera-se que cuide de sua família, especialmente no que concerne ao sustento. Da "atriz" esposa, que seja uma boa dona de casa e que cuide dos filhos e filhas. E assim por diante. Se uma pessoa não desempenha bem

10 A tradução literal de Mehrwert é "mais valor". 
seu papel social é fortemente reprimida pela sociedade. ${ }^{11}$ Naturalmente, cada cultura entende diferentemente o "papel" que diz respeito a cada "ator/atriz".

Alves enfatiza que, no mundo infantil, as crianças criam os papéis sociais e também o "script". Nada deve ser levado a sério, uma vez que tudo é criação humana. "Tudo não passa de brincadeira, de faz-de-conta. [...] Deus nos pôs a brincar. Convidou-nos a inventar nomes, a plantar jardins, a fazer amor... E daí surgiram os mundos da cultura" (ALVES, 1982, p. 178).

Mais importante ainda, no mundo infantil, o brinquedo faz com que a realidade se molde ao brincar, ou seja, é o desejo que dita as regras. As crianças são donas da situação, uma vez que, por meio da imaginação e fantasia, recriam a realidade. Se não estão contentes, refazem o script (ALVES, 1982, p. 180).

Contudo, para Alves, os adultos também brincam. Entretanto, não como fazem as crianças. Os adultos se identificam com seus papéis, tornando-se propriedade destes. Os papéis são os donos da realidade: possuem seus corpos e ditam suas identidades. Entretanto, para o teólogo brasileiro, é semelhante a ser possuído por um demônio. Não obstante, este espírito demoníaco não faz o indivíduo convulsionar, mas subir na vida, de forma que ninguém deseja sua expulsão (ALVES, 1982, p. 181).

\section{O brinquedo como denúncia}

Assim, para Alves, "A vida é dádiva de Deus para ser brincada" (1982, p. 181) e o brinquedo se torna uma denúncia da lógica que rege o mundo adulto. Em suas palavras:

O brinquedo, assim, se constitui numa denúncia da lógica do mundo adulto. As crianças se recusam a aceitar o veredito do "princípio da realidade" e separam um espaço e um tempo e tratam de organizá-los segundo os princípios da onipotência do desejo. E lá se move o grupinho de crianças, bem no meio do mundo adulto, como um protesto contra ele... Será algo semelhante a isto que Jesus tinha em mente, ao falar da necessidade de nos tornarmos como crianças? E começamos a suspeitar que o brinquedo está muito próximo da política... E as crianças não se conformam com este mundo, seguindo a admoestação de Paulo e, lá no fundo, ficam repetindo que "aquilo que é não pode ser verdade" (Bloch). Não é possível que a seriedade e a crueldade adulta seja aquilo de mais alto que a vida pode nos oferecer. E fazem o seu jogo de contas de vidro, e

11 Para Freud, por exemplo, o ego desenvolve mecanismos de defesa para proteger-se. Um deles é a "formação reativa", ou seja, a pessoa realiza o oposto do seu desejo. Por exemplo, uma jovem mãe que, irritada com o choro da criança, deseja matá-la, mas, por causa da repressão que isso causaria, reage com superproteção, o oposto do seu desejo inicial. No caso dos "papéis sociais", o ego da moça não poderia se desidentificar do papel de mãe, matando a criança, pois geraria repressão por parte da sociedade por não agir como uma "mãe". 
compõem um mundo em torno do prazer. Acreditam na imaginação e aceitam os seus oráculos. O mundo pode ser diferente. E, no brinquedo, esta coisa nova se oferece como aperitivo... (ALVES, 1982, p. 182-183).

Desta forma, o brinquedo se torna uma denúncia da lógica produtivista das atividades humanas e uma forma de imaginar um novo mundo, livre das "amarras" e "dispositivos" que nos impede de ser feliz.

Se os limites da linguagem formam os limites do mundo (Wittgenstein), então, a teologia, que se considera palavra que liberta, precisa se tornar amiga da palavra que brinca, uma vez que o brincar permite imaginar um novo mundo, esperançoso, uma vez que é palavra do corpo que fala a partir das experiências do próprio corpo (ALVES, 1982, p. 183-184).

Pode-se encerrar afirmando que, em Rubem Alves, a própria teologia é um brinquedo, e o ofício do/a teólogo/a é brincar com os símbolos sagrados.

\section{Conclusão}

A teologia do brinquedo de Rubem Alves, embora presente em um curto capítulo de seu livro "Variações sobre a vida e a morte", apresenta uma proposta muito inovadora: a partir do brinquedo, assumir a vida, o corpo e as atividades humanas como fins em si mesmos, uma vez que o brincar é um fim em si.

Brincar produz prazer. O desejo realiza-se. Brincando, as crianças dão asas à imaginação e recriam a realidade a partir de seu próprio faz de conta. É o desejo que rege as leis e não o contrário.

Assim, o brinquedo torna-se uma denúncia do mundo adulto. Brincar ensina que, além de a vida ser um dom de Deus e, portanto, fim em si mesma, permite imaginar uma nova realidade, de esperança e amor.

Isto não deixa, contudo, que se esqueça da realidade sofrida da América Latina e de todo o mundo. O corpo dos crucificados compõe a teologia, fala do corpo sobre o corpo, e a teologia do brinquedo de Alves recorda que suas vidas são dádivas para brincar, não podendo ser esquecidas e menosprezadas.

\section{Referências bibliográficas}

ALVES, Rubem. Variações sobre a vida e a morte: a teologia e sua fala. São Paulo: Paulinas, 1982.

ALVES, Rubem. A gestação do futuro. 2. ed. Campinas: Papirus, 1987.

ALVES, Rubem. Entre a ciência e a sapiência: o dilema da educação. São Paulo: Loyola, 1999.

CERVANTES-ORTIZ, Leopoldo. Sueños: la teología ludo-erótico-poética de Rubem Alves. 
México, D.C.: Centro Basilea de Investigación y Apoyo, 2005.

CERVANTES-ORTIZ, Leopoldo. O manancial eterno: teologia, poesia e liberdade em Rubem Alves. In: NUNES, Antônio Vidal. O que eles pensam de Rubem Alves: seu humanismo na religião, na educação e na poesia. São Paulo: Paulus, 2007.

DIAS, Romualdo. A letra do desejo. In: NUNES, Antônio Vidal. O que eles pensam de Rubem Alves: seu humanismo na religião, na educação e na poesia. São Paulo: Paulus, 2007.

DURKHEIM, Émile. Sociologia e educação. Lisboa: Edições 70, 2007.

DUSSEL, Enrique. Política de la liberación: historia mundial y crítica. Madrid: Trotta, 2007.

FODOR, Nandor; GAYNOR, Frank (Ed.). Freud: dictionary of psychanalysis. New York: Philosofical Library, 1950.

FREUD, Sigmund. Gesammelte Werke. Frankfurt am Main: Fischer, Vierzehnter Band, 1955.

FREUD, Sigmund. Gesammelte Werke. 5. Aufl. Frankfurt am Main: Fischer, Dreizehnter Band, 1967.

FREUD, Sigmund. Gesammelte Werke. 4. Aufl. Frankfurt am Main: Fischer, Fünfter Band, 1968.

HELLER, Sharon. Frend $A$ to Z. New Jersey: Wiley, 2005.

HORN, Christoph; MÜLLER, Jörn; SÖDER, Joachim (Hrsg.). Platon Handbuch: Leben, Werk, Wirkung. Stuttgart: Metzler, 2009.

HUNTER, David. Augustine on the body. In: VESSEY, Mark. A companion to Augustine. West Sussex, UK: Wiley-Blackwell, 2012.

LOHMANN, Hans-Martin; PFEIFFER, Joachim (Hrsg.). Freud Handbuch: Leben, Werk, Wirkung. Stuttgart: Metzler, 2013.

MÜLLER, Hans-Peter; STEFFEN, Sigmund (Hrsg.). Weber Handbucb: Leben, Werk, Wirkung. Stuttgart: Metzler, 2014.

NIETZSCHE, Friedrich W. Die fröbliche Wissenschaft. Leipzig: Fritzsch, 1887.

QUANTE, Michael; SCHWEIKARD, David (Hg.). Marx Handbucb: Leben, Werk, Wirkung. Stuttgart: Metzler, 2016.

REBLIN, Iuri Andréas. Outros cheiros, outros sabores: o pensamento teológico de Rubem Alves. São Leopoldo: EST, 2009.

SANTOS, Boaventura de Sousa. Um discurso sobre as ciências. 5. ed. São Paulo: Cortez, 2008. TANCARA, Juan Jacobo. Florestas profundas, mares desconhecidos: o corpo e a nostalgia no pensamento de Rubem Alves. In: NUNES, Antônio Vidal. O que eles pensam de Rubem Alves: seu humanismo na religião, na educação e na poesia. São Paulo: Paulus, 2007.

VIOTTO FILHO, I.A.T.; PONCE, Rosiane de Fátima; ALMEIDA, Sandro Henrique Vieira de. As compreensões do humano para Skinner, Paiget, Vygotski e Wallon: pequena introdução às teorias e suas implicações na escola. Psicologia da Educação, São Paulo, n. 29, p. 27-55, 2009.

WEBER, Max. Die protestantische Ethik und der Geist des Kapitalismus. Wiesbaden: Springer, 2016.

Submetido em: 10-5-2018

Aceito em: 13-4-2020 